\title{
Demystifying the Rise and Downfall of Communism in Malaysia (1968-1989)
}

\author{
Amelia Yuliana Abd Wahab, Wan Hashim Wan Teh, and Abdul Rahman Razak Shaik
}

\begin{abstract}
This paper seeks to demystify the factors contribute to the rise and downfall of Communist movement in Malaysia during the period of Second Emergency (1968-1989). The Communists were still active after Malaya (now Malaysia) obtained Independence in 1957. Their main target was to transform Malaysia into a Communist Republic. Thus, during this period of time, their movement was more aggressive compared during the First Malayan Emergency (1948-1960). Its took another twenty-one years for the Government of Malaysia to counter Communist guerrila warfare activities in the sovereign state of Malaysia. Rather than giving the definite answers for the communist problems or solutions, the heart of this paper seeks to explore the highly important facets of security complex environment in Malaysia that involved the communist struggle during the above-mentioned period of time. The rise and downfall of communism in their second wave of armed struggle were analysed based on the content analysis of the text from their clandestine radio, Suara Revolusi Malaya and Memoir of the Secetary-General of Communist Party of malaya (CPM), Chin Peng . The paper indicates the rise of communist in Malaysia because of factors such as effective usage of propaganda medium, China Cultural Revolution, material support from China, communal conflict, roles of Min Yuen and economic depression attracted the CPM to revive their struggle. The factors that contributed to communist downfall and failure to maintain power in Malaysia were includes disintegration within the party, discontinuation of communist propaganda medium and the counterinsurgency (COIN) deployed by Malaysian Government.
\end{abstract}

Index Terms-Communism, second emergency, downfall factors, rise factors, suara revolusi Malaya.

\section{INTRODUCTION}

The armed struggle of communist in Malaysia were not ended in 1960 eventhough government positively declared the country was free from communist guerrilla activities after the twelve-years bloody clashes in the First Malayan Emergency (1948-1960). The insurgency which was started as the struggle against the colonial domination was transformed into war against the sovereign state of Malaysia(formerly known as Malaya before September, 1963). This paper seek to demystify the factors that motivate the second wave of communist armed struggle that led to Second Emergency in Malaysia (1968-1989). The history of communism in Malaysia can be traced way back in year 1930, precisely on 30 April 1930 as highlighted by the Chin Peng, the Secretary-General of the communist party [1] indicated the date as the Founding Day of the

Manuscript received July 14, 2016; revised October 23, 2016.

The authors are with Faculty of Defence Studies and Management, National Defence University of Malaysia, Malaysia (e-mail: amelia4433@yahoo.com).
Communist Party of Malaya (CPM) in Peninsula Malaysia.

The experiences collaborating with Forces 136 and training received by the members of CPM from the 101 Special Training School (101 S.T.S) gave the advantage to them in practising the art of guerilla warfare in countering the British during the First Malayan Emergency. Force 136 was the code-name given to a special underground division and their activities were confined to the Southeast Asia countries occupied by the Japanese, while the objectives for the formation of 101 STS were to unite all races in Malaya and to form a single opposition front to help the British check the advance of Japanese forces, as well as to train them in guerrilla warfare [2] This group formed their own core of the guerrilla force known as the Malayan Peoples Anti-Japanese Army (MPAJA) and continue to receive training and weapon supply from STS in Singapore. The first detachment was recognised as having established at Serendah, less than 15 miles north of Kuala Lumpur on 10 January 1942 [1].

On 1 December 1945, the MPAJA was disband and some 5, 000 weapons as highlighted by Chin Peng [1] has been taken and hide in the jungle by the communists and this supply of weapons were lated used by communists in the First Malayan Emergency countering the British Colonialists. MPAJA was renamed to the Malayan Races Liberation Army (MRLA) on 1 February 1948, and their members at the time of First Malayan Emergency were approximately 12,000 to 14,000 and majority ninety percent were from the Chinese ethnic group [3]. The state of emergency was then declared on 18 June 1948 marked the start of First Malayan Emergency.

In maneuvering communists movement in Malaya, the CPM formed two groups that had different aims and responsibilities. The first was a small army groups that operating from a secret jungle bases, many of the old jungle bases in which they had lived with Force 136 and the second group known as Min Yuen (Masses Movement) civilian supporters [4]. Min Yuen was the communist symphatizers whom provided information, medical supplies, food and material required by the communists. It is emphasized by Chin Peng [1], the Briggs Plan strategy of relocating squatters in 'New Villages' organised by Lieutenant- General Sir Harold Briggs, as the Director of Operations in countering communists in Malaya on June 1950 somehow successfully disrupted the communist effort to communicate with their Min Yuen. All this while, the communists has cultivated Min Yuen in the squatter communities and at the supply lines.

'The battlefield outlook for our forces by this time was indeed gloomy. The Briggs Plan with its objective of starving us out of the jungle had been the foundation of a 
devastating effective programme' [1].

Furthermore, Chou En Lai's performance at the Bandung Conference, Indonesia on April 1955 gave a significant impact that boosted the image of China towards the Chinese Communists movement especially in the Third World states in their struggle to fight against the 'imperialists' [1], [5].

The First Malayan Emergency was last for twelve-years and Malaya gained it independence on 31 August 1957. Although there was an offer of amnesty for communists to surrender their armed struggle before 1960 through Baling Talks, but the attempt was failed.

'The most important decision taken at this post-Baling conference concerned the military stance we should adopt from the point onwards. We studied three options. We could lower the intensity of our attacts. We could increase them. Or we could generally maintain the war at its then current level. Each was examined for the impact it would likely have on the CPM's long -term prospects -both military and political' [1].

Thus, after the post Baling Talks, the communist took the first option that was to lower the intensity of their movement for a short period of time before they decided to increase their guerrila warfare activities. At this quiet time, the communist shapern their guerrilla strategy, not only in jungle or villages, but also in urban areas.

\section{Methodology}

The research paper utilizes the content of the text from primary sources, the transcript of clandestine CPM's radio, Suara Revolusi Malaya and from the memoir of SecretaryGeneral of CPM Chin Peng. This is a qualitative method that explain the reason of Communist reactive their armed struggle in Malaysia and their failure to maintain power in the soil of Malaysia.

\section{SeCond WAVE of ARMed Communism In Malaysia}

The second wave of armed communists struggle in Malaysia was started in 1968, before CPM return to armed struggle again, there were active with the recruitment of new communist members in order to expand their guerrilla forces. They used the platform of political education and much effort in conducting a heavy programme of lectures, and by time this, their aim was not solely to subvert only one ethnic group, the scope of communists' targeted audiences expand to other races.

'With our new programme and access to funds, we launched the first recruitment drive in mid-1961. By 1964, our guerrilla strength had grown to around 800 . This time we had considerable success winning over and recruiting local Muslims' [1].

In return wave of armed communist struggle, the CPM had renewed their policy and strategy. Mao Zedong predicted the revive of communist armed struggle would spread across Southeast Asian countries, one after another fall into the communists' hand just like the Western 'Domino Theory', from Vietnam, Cambodia, Thailand and Malaysia [1].

The foreign imperialists was not the main target of the second wave of armed communist struggle as their dream to establish a Communist Republic was not achieved just yet during the First Malayan Emergency [6] . Among other reason for the second wave of communists armed struggle as been highlighted by Chin Peng was to counter-attack the continuation of colonialist 'puppet'. The former or latter end, might justified their means for the second communist armed struggle.

'I had to be a liberation fighter. If you had lived in a Malayan rural population centre like Setiawan and observed how dismissive the British colonials were of our lot in the 1930s, you would find it easier to understand how attraction of a Communist Party of Malaya cound take hold. And if you had gone through the gastly period of the corrupt British Military Administration immediately after the Japanese capitulation and seen the wholesale poverty that pervaded after years of Japanese atrocities, you would not quick to say that I should have been cool-headed and taken an easier road. I could not compromise with the Japanese, neither could I have worked within a system that perpetrated the continuation of British colonialism' [1].

The armed communists started their guerrilla warfare activities back in 1968 and their first targeted areas was in the Northern Perak region in Peninsula Malaysia. The rationale to chose the Northern part of Peninsula because of the strategic location for the communists forces to manoeuvre from Southern Thai down to Peninsula Malaysia. The Northern region also was one of communists playground during First Malayan Emergency.

'By 1968 we were ready to move some of our units south of the border again. In the intervening years our base camp locations had undergone some strategic repositioning. We started by sending groups to reconnaitre our old areas of operation' [1].

The communist forces gained drastic momentum after the racial riot 13 May 1969 in Kuala Lumpur. As acknowledged by Chin Peng [1], the incident contributed to a sigificant number of a new membership that support their communist guerrilla movement, and at this point approximately 1, 600 hardcore communist fighters supported them. Some were reluctant to support the policy of the government, they were more keen to associate themselves with the communist ideology.

The beginning of the communist second wave of armed struggle in Malaysia shown the fruitful impact. The communists forces in Malaysia was glorify by the other communist parties around the world. In the $40^{\text {th }}$ Anniversary of the CPM, Chinese Communist Party (CCP) praises the success achieved by CPM in its protracted armed struggle to realise the liberation of Malaya.

'The CCP firmly believes that the CPM will certainly achieve final victory in establishing a Malayan People's Republic by persisting in its correct line of using the countyside to surround the city and seizing political power through armed struggle' [7].

The insurgency in Malaysia thus continued for twentyone years and this led to the undeclared low-intensity conflict (LIC) between the communists and the Malaysian Government. The communists increased their attacks, ambushes of military convoys, bombing of national monuments, assasinating of marked police officers including 
the Inspector General of Police (IGP) and political enemy target [8]. The second wave of armed communist struggle that brought the Second Emergency in Malaysia finally wound down through the peace treaty known as Hat Yai Peace Accord, the peace aggrement was signed on 2 December 1989 in between CPM, the Malaysian Government and Thai military commanders in Hat Yai, Southern Thailand.

\section{THE RISE AND DOWNFALl OF COMMUNISM IN MALAYSIA}

The heart of this paper is to highlight the factors that contribute to the rise and downfall of communist struggle during the Second Emergency in Malaysia. The identification of these factors are very critical in order to understand the factor behide their motivation and factor that demoralize their guerrila forces.

Figure 1 below categorize factors that contribute to the rise and fall of communism in Malaysia. This paper identify six factors that motivate the communism to start their second wave or armed struggle that includes China material support to CPM, role of Min Yuen, the China Cultural Revolution, communal 1969 conflict, fall of Saigon and economic depression. The three factors that demoralize their movement were fraction within the CPM, discontinue of their propaganda radio and counterinsurgency (COIN) deployed by the authority, the Malaysian Government.

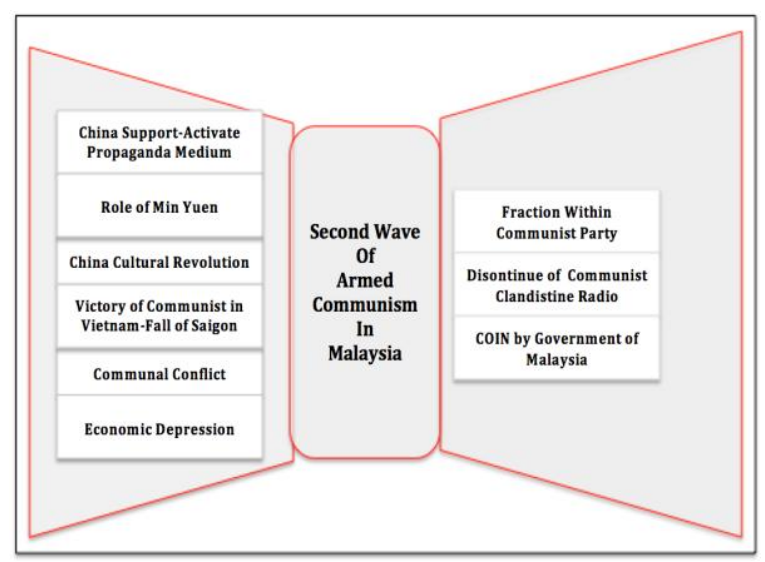

Fig. 1. The factors contributed to the rise and downfall of communism in Malaysia.

First of all, the CPM obtained material support from China in order to enhance and strengthen of the propaganda medium. The radio has been used as the means of communist propaganda and they successfully set up 'Suara Revolusi Malaya', which was funded by China, in the effort and requested made by Chin Peng, the Secretary-General of CPM. All the contents in this clandestine radio were vetted by him and broadcasted throughtout Malaysia and Singapore.

'In Hunan, the CPM was allocated facilities in the middle of a heavily restricted military area bearing the codename Project 691. Our broadcasts commenced from Hunan in November 1969. We decided on the call-sign 'Suara Revolusi Malaya'- Voices of Malayan Revolution [3].

Secondly, the activate role of Min Yuen boosted the efficiency of CPM's movement in facing the big-scale offensives operations launched by the Malaysian Government. Min Yuen carried out extensive propaganda activities in behalf of the communist. There were organised in the spotted guerrilla zones along the border and in the rural areas of Perak, Kedah and Kelantan to forged closer links within the masses to obtain their whole-heart support [9]. Chin Peng also formed the small squad known as the Shock Brigades approximately 2000 communist guerrillas. There were deployed to smoothen communist movement from north to south down of Peninsula Malaysia and at the same time, this unit responsible to influence and subvert the population to support the communist ideology.

Thirdly, Great Proletarian Cultural Revolution inspired by Mao Zedong began in 1966 in China gave a significant motivation to the CPM armed struggle in Malaysia. The very first time, a Communist leader, Mao Zadong called for publicly attacking and actually destroying the party, its elites and the structures and institutions of the state [10]. The strategy was deployed in the sense of Marxist's thought, a reformation from within, by the masses in the name of the proletarian revolution in countering against bureaucratic and neo-capitalist structure. He further initiated a Socialist Education Movement designed to drum the younger generation and their wavering local leaders the idea that capitalism had already failed the Chinese and not be revived [11]. Mao's called this revolution for 'swimming against the tide'. The China's urban youth known as a Red Guard destroyed many priceless country cultural artefacts includes the artworks and paintings, smashing ancient temples, tearing down reactionary monuments and the grave of Confucius was desecrated. For communist guerrilla forces in Malaysia, this Cultural Revolution shown the power of the population in toppling the government. This incident inspired the communist to use hard power in countering the authority.

'As a month passed, I myself became caught up in the Cultural Revolution's fervour. I felt obliged to become directly involved in what I then regarded as an important milestone in the evolution of world communism' [1].

For the CPM, the launched of Cultural Revolution by Mao Zedong was congruent with their objective of armed struggle in Malaysia. Chin Peng make it publicily the intention of communism armed struggle to have another China Cultural Revolution through Malayan Revolution.

'The CPM is a proletarian revolutionary Party armed with Marxism-Leninism- Mao Tse Tung thought and the force at the core defending the interests of the Malayan people of all nationalities and leading the Malayan revolution' [12].

The considerable motivation for CPM armed struggle in year 1975 gained from the Vietnam War, when Saigon the South city in Vietnam was fallen under the hand of Vietnam Workers' Party and South Vietnam National Front . In congratulatory messages on 8 May 1975 broadcasted in Suara Revolusi Malaya, CPM praise the splendid achievement of the Vietnamese people who engaged in the armed struggle for thirty years and persisting in the protracted People's War in combating U.S imperialism. This acted proven the capability of communist forces in combating the Superpower-U.S imprealists even without the advancement of weaponry. The fall of Saigon instigated the 
morale of communist guerrila forces in Malaysia.

'The people of various countries including the Malayan people regard your victory as their own' [12].

Another important pull factor for the returning of CPM armed struggle was the incident of racial riot 1969. This incident clearly shown the fraction of multi-ethnic society in Malaysia, especially between two major ethnic groups. The situation of unrest gave an opportunity for CPM to recruit more followers and expand their forces. The situation became more worst in year 1974 because of the economic recession and much of Malaysian economic depend more on the export of rubber and tin, when the prices fell, tin mines, rubber estates and industrial enterprises were hit hard and this situation cause the increase of unemployment and underemployment [13]. The economic slump gave a perfect chance for communist guerrilla forces in recruiting new members and supporters.

The strength of communist party in Malaysia decreased when they were not unite under one leadership. Firstly, the factor contributed toward the armed communist second wave struggle that led to their downfall was CPM's disintegration from within that divide the comunist party into three factions. The main body of CPM was still under the command and control of Chin Peng and had been active in the Thai-Malaysia border region, another two factions were the Revolutionary Faction (RF) and the MarxistLeninist Faction (ML) [3].

'The Sadao lot proclaimed themselves The Communist Party of Malaya (RF) and Betong West identified their party as the Communist Party of Malaya (ML)' [3].

Thus somehow, the disintegration of the communist party contributed to more complex command and control to achieve mutual aim and obejctive during communist second wave of armed struggle.

Suara Revolusi Malaya, the clandestine radio that propogate the communism agenda was then instructed to closed down after being aired without any interruption until in the year 1980. The instuction to stop the operation of communists radio in Malaysia was made by Deng Xioping, the successor of Mao Zedong. The radio at the time was the best medium of instrument in dessiminate idology and activities of communism in Malaysia. The closure of Suara Revolusi Malaya lowered and demoralized the communist guerrilla forces. This is because, the radio had been used to the fullest by the communists. All their activities had been recorded and aired to wide coverage of population. Without this clandistine radio, the communist had a limited ability in dessiminating information.

Another factor added to the downfall of communism in Malaysia was the Counterinsurgency (COIN) strategy deployed by the Government of Malaysia. There were various approaches implemented in order to curb the penetration of communism ideology toward the population. The approach strategize by the Malaysian Government was against the conventional pattern of Big Power or Idealists by using strong hard power to gain better security posture. The Malaysian government adopted the more advanced, encompassing and holistic approach that defines national security as the capacity of the society to protect individuals, groups and the nation from physical and socio-economic danger [14].
The development was the main task in countering the communism agenda from insinuated to the population. Tun Abdul Razak, the Malaysian Second Prime Minister championed this strategy through his early ground work of security and development (KESBAN) in order to win the heart and mind of Malaysian in supporting the government agenda and policy.

'The greatest safeguard of our country's sovereignty is not only defence but even more so, development' [15].

Looking at the positive consequences of Tun Abdul Razak's approach, his successors then carried the security and development strategy in order to counter the communism until the armed communist defeated in year 1989.

On the military aspect, The Malaysian Armed Forces (MAF) played a pivitol role in supporting the Government policy in countering the communists. The tactical manoeuvres in jungle warfare and the finest strategic offensive art of war against the communist helped the Malaysian government in their COIN against communist during the Second Emergency. The strategy of KESBAN was cleary illustrate by the General Tan Sri Zulkifli [16], the combination of security forces- the Military and Police together with the political leaders and civilian government agencies need to collaborate with each other in deploying the good COIN strategy.

'Running a KESBAN operation is like conducting an orchestra. The musical instruments are of diverse types. Yet they all contribute toward creating the same music. Every single musician has to be good at playing his musical instrument. They all read the same note. They also follow the lead from one single conductor who is in charge of the performance' [16].

The formation of National Operations Council (NOC) by Tun Abdul Razak aftermath the racial incident 1969 set an example the good COIN need to look merely on many aspects, for the period of Second Emergency, the Security and Development was the suitable COIN strategy in countering the communism.

The above-mentioned factors contribute to rise and fall of communism in Malaysia, precisely in Peninsula Malaysia after the First Malayan Emergency. The Malaysian Government had successfully ended the low-intensity conflict with the peace treaty. The long struggle of communism approximately forty-one years or more in Malaysia shown communists determination to uphold the cause that they think right for them and for all. In the case of Malaysia, the communism left significant marked in the history of the state. There are many lives had been sacrified in the cause of their action, including the innocences.

\section{CONCLUSION}

The end of the First Malayan Emergency led one of the great turning-points for the communists in preparing their guerrila forces for the second wave of armed struggle in Malaysia. The second wave of communism armed struggle led to the undeclared low-intensity conflict or known as Second Emergency. This LIC last for twenty-one years until on $2^{\text {nd }}$ December 1989, the Hat Yai Peace Treaty was signed 
indicated the end of communism in Malaysia, in this case Peninsula Malaysia.

The 'coming-back' of communism in Malaysia back in 1968 gave the challenges to Malaysian Government in crafting the best-suited strategy for the state survival. The paper seek the history of communism in Malaysia by demystify the possible factors that instigated the communist armed struggle for their second wave movement in Malaysia.

Malaysia before and now are significantly different, the improvement and advancement of economic, armed forces, education, science and technology and much more reflected the drastic change but the history remain. To learn, relearn and unlearn from the history is upmost crucial as being told by the Malaysian historian, Wan Hashim Wan Teh, understanding the past is sine quo non to understand present and future character of threat to Malaysian national security.

\section{REFERENCES}

[1] C. Peng, Alias Chin Peng-My Side Of History, Media Masters Pte Ltd Singapore, 2003.

[2] W. H. W. Teh, Role of the Malay Guerillas FORCE 136, ITNMB, 2010.

[3] L. Comber, 13 May 1969 the Darkest Day in Malaysian History, Marshall Cavendish, 2009.

[4] N. Barber, The War of the Running Dogs, William Collins, 1971.

[5] R. Lowenthal, World Communism-The Disintegration of A Secular Faith. Oxford University Press, 1966.

[6] N. Barber, The War of the Running Dogs, William Collins, 1971.

[7] Suara Revolusi Malaya, The Transcript of Radio Broadcasted on $10^{\text {th }}$ May 1970 .

[8] B. K. Cheah, "The communist insurgency in Malaysia: Contesting the nation-state and social change," New Zeland Journal of Asia Studies, 2009.

[9] Suara Revolusi Malaya, Transcipt of Radio Broadcasted on $29^{\text {th }}$ December 1971.

[10] T. Heberer, "The great proletarian cultural revolution: China's modern trauma," Journal of Modern Chinese History, Routledge, 2009.

[11] J. Clements,. Mao Zedong, Haus Publishing London, 2006.

[12] Suara Revolusi Malaya, The Transcript of Radio Broadcasted on $5^{\text {th }}$ May 1975.

[13] R. Stubbs, Peninsular Malaysia: New Emergency, 1976.

[14] Z. Hadi, "Malaysian emergencies-anthropological factors in the success of Malaysia's coin," Thesis submitted to Naval Post Graduate School, California, 2004.

[15] A. Razak, Speeches on Rural Development and Defences, 1970.

[16] Z. Z. Abidin, "Inculcating professionalism in defence for national development with special reference of KESBAN concept," in Proc. $8^{\text {th }}$ International Conference, KDU, 2015.

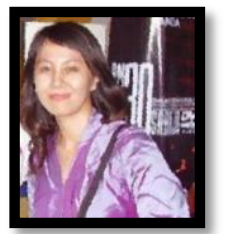

Amelia Yuliana Abd Wahab was born in the southern region of Peninsula Malaysia, Johor Bahru. She is a PhD Candidate in Faculty of Defence Studies and Management, National Defence University of Malaysia. She research interests includes are new media, media and propaganda, policy and security studies and Malaysian history studies.

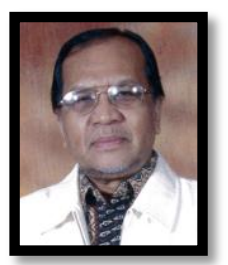

Dato' Wan Hashim Wan Teh was born in Gerik, Perak, Malaysia. Currently he is a emeritus professor and a dean at the Faculty of Defence Studies and Management, National Defence University of Malaysia. He obtained his B.A hons and a M.A in antropology and sociology from Monash University and a PhD in sociology of development from Manchaster University, UK. A former politician and previously won the General Election (2004) and appointed as a member of Parliament (MP) for Gerik, Perak. He is a Malaysian historian and his area of expertise includes development and civilization studies, civil-military relations, ethnic relations and military history.

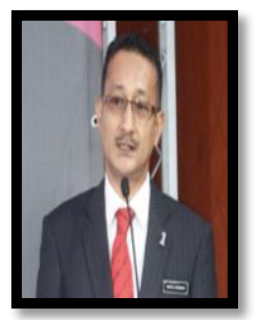

defence management.
Abdul Rahman Razak Shaik was born in Northern State of Perak, Malaysia. He worked as an associate professor at the Faculty of Defence Studies \& Management, National Defence University of Malaysia. He received his M.S in corporate communication and a $\mathrm{PhD}$ in humanity communication from University PUTRA Malaysia. He Holds several post in public institutions and his area of interest includes political communication, media studies and 